\title{
Biochar research activities and their relation to development and environmental quality. A meta-analysis
}

\author{
Khalid Mehmood $^{1}$ • Elizabeth Chávez Garcia ${ }^{2}$ - Michael Schirrmann ${ }^{3}$. \\ Brenton Ladd $^{4,5}$ • Claudia Kammann ${ }^{6}$ • Nicole Wrage-Mönnig ${ }^{7}$. Christina Siebe ${ }^{2}$. \\ Jose M. Estavillo $^{8}$ - Teresa Fuertes-Mendizabal $^{8} \cdot$ Mariluz Cayuela $^{9} \cdot$ Gilbert Sigua $^{10}$. $^{10}$ \\ Kurt Spokas $^{11}$ - Annette L. Cowie ${ }^{12}$. Jeff Novak ${ }^{10}$ • James A. Ippolito ${ }^{13}$. \\ Nils Borchard ${ }^{1,14,15}$
}

Accepted: 16 May 2017 / Published online: 6 June 2017

(C) The Author(s) 2017. This article is an open access publication

\begin{abstract}
Biochar is the solid product that results from pyrolysis of organic materials. Its addition to highly weathered soils changes physico-chemical soil properties, improves soil functions and enhances crop yields. Highly weathered soils are typical of humid tropics where agricultural productivity is low and needs to be raised to reduce human hunger and poverty. However, impact of biochar research on scientists, politicians and end-users in poor tropical countries remains unknown; assessing needs and interests on biochar is essential to develop reliable knowledge transfer/translation mechanisms. The aim of this publication is to present results of a metaanalysis conducted to (1) survey global biochar research
\end{abstract}

Nils Borchard

nils.borchard@rub.de; nils.borchard@uni-bonn.de

1 Agrosphere Institute (IBG-3), Forschungszentrum Jülich GmbH, 52425 Julich, Germany

2 Departamento de Edafología, Instituto de Geología, Universidad Nacional Autónoma de México, Ciudad Universitaria, C.P. 04510 Cuidad de Mexico, Mexico

3 Leibniz Institute for Agricultural Engineering and Bioeconomy, Max-Eyth-Allee 100, 14469 Potsdam, Germany

4 Universidad Científica del Sur, Panamericana Sur km 19, Lima, Peru

5 Evolution and Ecology Research Centre, School of Biological, Earth and Environmental Sciences, University of New South Wales, Sydney, NSW 2052, Australia

6 Department of Soil Science and Plant Nutrition, Geisenheim University, Von-Lade-Straße 1, 65366 Geisenheim, Germany

7 Faculty of Agricultural and Environmental Sciences, Grassland and Fodder Sciences, University of Rostock, Justus-von-Liebig-Weg 6, 18059 Rostock, Germany

8 Department of Plant Biology and Ecology, University of the Basque Country (UPV/EHU), Apdo. 644, E-48080 Bilbao, Spain published between 2010 and 2014 to assess its relation to human development and environmental quality, and (2) deduce, based on the results of this analysis, priorities required to assess and promote the role of biochar in the development of adapted and sustainable agronomic methods. Our main findings reveal for the very first time that: (1) biochar research associated with less developed countries focused on biochar production technologies $(26.5 \pm 0.7 \%)$, then on biochars' impact on chemical soil properties $(18.7 \pm 1.2 \%)$, and on plant productivity $(17.1 \pm 2.6 \%)$; (2) China dominated biochar research activities among the medium developed countries focusing on biochar production technologies $(26.8 \pm 0.5 \%)$ and

9 Department of Soil and Water Conservation and Waste Management, CEBAS-CSIC, Campus Universitario de Espinardo, 30100 Murcia, Spain

10 Agriculture Research Service, Coastal Plains Research Center, United States Department of Agriculture, 2611 West Lucas Street, Florence, SC 29501, USA

11 United States Department of Agriculture, Agriculture Research Service, Soil \& Water Management Research Unit, University of Minnesota, 439 Borlaug Hall, 1991 Buford Circle, St. Paul, MN 55108, USA

12 New South Wales Department of Primary Industries, University of New England, Armidale, NSW, Australia

13 Department of Soil and Crop Sciences, C127 Plant Sciences Building, Colorado State University, Fort Collins, CO 80523-1170, USA

14 Center for International Forestry Research, Jalan CIFOR, Situ Gede, Sindang Barang, Bogor 16115, Indonesia

15 Institute of Geography, Soil Science/Soil Ecology, Ruhr-University Bochum, Universitätsstrasse 150, 44801 Bochum, Germany 
on use of biochar as sorbent for organic and inorganic compounds $(29.1 \pm 0.4 \%)$; and (3) the majority of biochar research $(69.0 \pm 2.9 \%)$ was associated with highly developed countries that are able to address a higher diversity of questions. Evidently, less developed countries are eager to improve soil fertility and agricultural productivity, which requires transfer and/or translation of biochar knowledge acquired in highly developed countries. Yet, improving local research capacities and encouraging synergies across scientific disciplines and countries are crucial to foster development of sustainable agronomy in less developed countries.

Keywords Sustainable development goals - Soil fertility · Plant productivity $\cdot$ Carbon sequestration $\cdot$ Agriculture $\cdot$ Food security

\section{Contents}

1 Introduction

2 Material and Methods

2.1 Literature search and topical classification of biochar research

2.2 Compiling and aggregation of environmental and socio-economical indices

2.3 Relation between biochar research topics and aggregated environmental and socio-economic indices

3 Results and discussion

3.1 Influence of development on biochar research

3.2 Influence of GHG emission on biochar research

3.3 Influence of environmental resilience and agriculture on biochar research

4 Conclusion and implication for future activities

Acknowledgment

References

\section{Introduction}

The world's population is expected to reach 9 billion by 2050 (Godfray et al. 2010), which will require an increase of $>50 \%$ in agricultural food supply to meet the growing demand (Mueller et al. 2012; FAO 2013a; Paul et al. 2009; FAO 2009). Over the same period, climate change, water scarcity and land degradation are expected to negatively impact agricultural productivity, which may severely challenge our ability to meet this required demand of food production (FAO 2013a). People that are already poor and vulnerable may be the worst affected, despite having contributed least to climate change. Since the global challenges of hunger, nutrition and climate justice are strongly connected (Gregory et al. 2005; FAO 2009), it is critical to minimize further land use change, land degradation and greenhouse gas (GHG) emissions. The complex interrelationship of agricultural production, water availability, and soil health will underpin the possibilities for achieving the Sustainable Development Goals of the United Nations Sustainable Development Solutions Network (Sustainable Development Solutions Network 2015). Managing land degradation is a central challenge that simultaneously addresses environmental and development objectives.

The literature often reports that the majority of land degradation is caused by human activity (e.g., overgrazing, deforestation, agricultural mismanagement or mining) that stimulates the loss of organic matter due to erosion, physical and chemical soil deterioration of the soil (Jie et al. 2002; Barman et al. 2013; Oldeman 1994; Oldeman et al. 1991). This in turn reduces soil productivity and the provision of crucial ecosystem services (ELD Initiative 2015; Barman et al. 2013). Moreover, agriculture is one of the major $\mathrm{GHG}$ emitters (i.e. $\mathrm{CO}_{2}, \mathrm{CH}_{4}, \mathrm{~N}_{2} \mathrm{O}$ ) accelerating global warming (IPCC 2013, 2000), which almost certainly will negatively impact agriculture (Gregory et al. 2005). This contribution will even be enhanced with future climate change by positive feedback effects of elevated $\mathrm{CO}_{2}$ on non- $\mathrm{CO}_{2} \mathrm{GHG}$ formation (van Groenigen et al. 2011), rising temperatures and more extreme weather events, such as droughts and flooding. Thus, agricultural management requires adaptation and mitigation strategies to reduce GHG emissions while simultaneously increasing crop productivity (UN 2015; FAO 2013a; Gregory et al. 2005).

One adaptation strategy is to apply organic matter to agricultural lands. Application of organic matter has shown to improve the properties of soils and agricultural productivity (Lal 2006; Lal et al. 2007; FAO 2013a). However, soil organic matter can decompose quickly (Kögel-Knabner and Amelung 2014; Schmidt et al. 2011; von Lützow et al. 2006), necessitating repeated applications (Gattinger et al. 2012; Lal 2006). Thus, the usage of stable compounds such as biochar as soil amendments, or as part of organic amendments such as compost or manure, may be a cost-effective and low-risk alternative to improve agricultural productivity and to mitigate climate change over the long-term (Gurwick et al. 2013; Glaser et al. 2002; Crane-Droesch et al. 2013; Borchard et al. 2014a; Hernández-Soriano et al. 2015).

Among the long-term soil restoration techniques, biochar and all its modified forms (e.g. loaded with nutrients, activated to change porosity and chemical properties) belong to the more promising soil GHG mitigation amendments (Joseph et al. 2013; Novak et al. 2014; Kammann et al. 2015; Schmidt et al. 2015; Mukherjee et al. 2014). Biochar is the solid product that results from pyrolysis of organic materials (Verheijen et al. 2010; Sohi et al. 2010; Keiluweit et al. 2010) having properties that depend on used technology and feedstock (Keiluweit et al. 2010; Libra et al. 2011; Enders et al. 2012). How biochar affect soil properties and plant performance has been reasonably assessed (Crane-Droesch et al. 
2013; Jeffery et al. 2011; Sohi et al. 2010; Liu et al. 2013). Many investigations have shown that the application of biochar to soil influences soil physico-chemical properties and improves soil functions such as water and nutrient holding capacity (Crane-Droesch et al. 2013; Mukherjee and Lal 2013; Ajayi and Horn 2016; Jeffery et al. 2011; Haider et al. 2016). These characteristics make biochar, applied alone or as its mixture with other organic amendments (e.g. compost, manure, digestate etc.), a potentially attractive tool to improve agricultural productivity (Schulz et al. 2013, 2014; Prost et al. 2013; Liu et al. 2013). Recently, Joseph et al. (2013) and Novak and Busscher (2013) introduced tailor-made and designer biochars having specific properties adapted to their potential use. Despite the uncertainty about exact mechanisms of improvement, biochar has been most successful at improving crop yields on highly weathered soils (Crane-Droesch et al. 2013; Liu et al. 2013; Schulz et al. 2013; Jeffery et al. 2011; Lehmann and Rondon 2006; Cornelissen et al. 2013; Obia et al. 2016). Highly weathered soils are typical for humid (e.g. tropical) zones where low agricultural productivity needs to be improved to reduce poverty (Barrett and Bevis 2015; Folberth et al. 2016; Lal 2006). Thus, it is essential to transfer/translate knowledge about the use of biochar as soil amendment to scientists, politicians and end-users in poor tropical countries, where improved soil management strategies in combination with new crop varieties (e.g., droughttolerant ones) can likely maximize beneficial effects on crop yield and climate, fostering further implementation of climatesmart agricultural practices.

There are several examples where biochar programs or activities bridge research, policy and end-users (Fig. 1). For example, the International Biochar Initiative (www.biocharinternational.org), the British Biochar Foundation (www. britishbiocharfoundation.org), and the Alberta Biochar Program in Canada (www.albertatechfutures.ca) are providing organizational structure for these outreach activities. Additionally, there are numerous research networks (e.g. European Biochar Research Network [www. cost.european-biochar.org]; UK Biochar Research Centre [www.biochar.ac.uk], Biochar for Sustainable Soils (B4SS) project [http://biochar.international]) and numerous local efforts (see also http://www.biochar-international.org/ network/communities) that are incorporating biochar as an axis of research and dissemination. Undoubtedly, dissemination is important to convey scientific knowledge of biochar uses and its potential benefits to policy makers and practitioners. Designing and implementing new technologies (e.g. engineered biochar) and selecting biochars to address specific soil limitations requires scientific exchange of results and information among scientists, stakeholders, and potential users (Fig. 1). Creating regional and worldwide scientific exchange networks (e.g. African Biochar Expert Group [http://www.siani.se/expert-groups/african-biochar],
Design Char4Food [https://www.faccejpi.com/content/ download/4466/41944/version/1/file/Designchar4Food.pdf]), will guide the development of integrated soil management strategies into a coherent global policy platform that may sustain agricultural productivity and ensure food security in the challenging times ahead (Fig. 1). To our knowledge, there has been no citable literature that has closely examined the extent of biochar adoption by countries. Moreover, information on current funding levels for biochar research by individual countries or states is sparse in the literature.

Based on the critical need for promoting the sound adoption of biochar in agricultural practices around the world, we report on biochar research activities on a global scale to identify countries that promote and fund biochar research. Information on countries' socio-economic status and their impact on the environment were used to assess how human development and environmental properties and characteristics affected biochar research. Biochar research itself is a young research discipline (Gurwick et al. 2013), thus we assumed that the countries' interest and investment in promoting biochar research would be manifested in international publication activity.

\section{Material and methods}

\subsection{Literature search and topical classification of biochar research}

An exhaustive systematic literature search (Uman 2011) was conducted for peer-reviewed articles published between January 1, 2010 and September 20, 2014 in the Web of Science database (Thomson Reuters) using the term "biochar" in the "topic" field. We excluded search results that were published in languages other than English $(n=16)$, or for which only an abstract was available. The remaining pool of 1250 articles was categorized into three publication types: (a) Original research, (b) Reviews, or (c) Editorials/Comments. Editorials/Comments included notes and short communications presenting brief and novel scientific findings.

From the publication database, we also extracted information about "country of origin" of the research, "country/origin of funding" and "country of institution to which authors are affiliated". Compiling "country of origin" was simple for publications indicating location or multiple locations of research (e.g. field trial, laboratory etc.). In case of lacking information on the "country of origin" we assumed that research (e.g. laboratory experiment) was performed in the first author's country (i.e. affiliation) or, in case of multiple affiliations in country, where majority of authors was affiliated. Screening articles published within 5 years (see above) may risk a publication bias due to time lag until publication and significance or novelty of biochar research results (Jennions et al. 2013), 


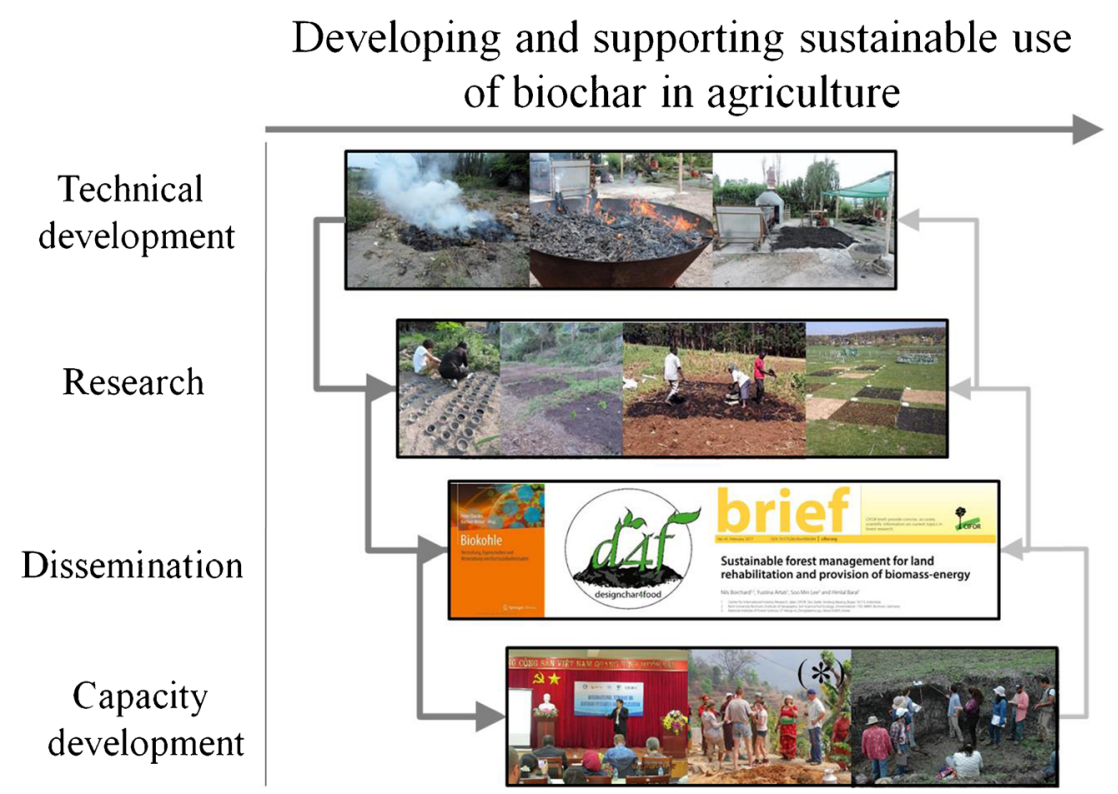

Fig. 1 Developing sustainable agriculture adapted to cultural and geophysical circumstances requires complex approaches that include technical development, research, knowledge transfer/translation and capacity development. Increasing agricultural productivity, improving food quality and reducing greenhouse gas emissions from agriculture are global challenges as demonstrated by initiatives that assess, promote

which may affect publication activity. Typically, as knowledge gaps have been addressed, new research must be more sophisticated, in terms of methods applied and hypotheses tested, which may make it difficult for developing country researchers to publish their research if they are lacking in expertise and facilities to undertake process-oriented research. Thus, time related publication bias was addressed in this study by assessing publication activity also annually. Assessing "country/origin of funding" required an acknowledgment that clearly addressed funding source, which was linked to a country or multiple countries. The authors' affiliations were explicitly added into our data base for authors affiliated to institutions located in developing countries. However, we had to accept bias due to hidden relation of authors to developing countries, e.g. a research student originally from China, but affiliated to an institution in Australia is considered to be an Australian. Multiple entries were allowed in case of multiple countries of origin, funding and authors' affiliation. Thus, the final dataset contained country-related information and topic classification.

Relative values $(R)$ of environmental and socio-economic indices explained in section 2.2 and results shown in Figs. 4 and 5 were determined using Eq. (1):

$R=\left(\frac{n_{i}}{n_{t}}\right)^{*} 100$

Where $n_{i}$ is the number of research activities related to a specific biochar research topic and $n_{t}$ is the total number of and teach methods for using biochar in agriculture. Arrows indicate simple relations and feedback loops between technical development, research, knowledge transfer/translation and capacity development. A single asterisk indicates the photo: Hand-Peter Schmidt, Ithaka Institute for Carbon strategies, Switzerland

research activities found. Means are shown with their standard errors.

\subsection{Compiling and aggregation of environmental and socio-economical indices}

Additional information was gathered to link biochar research topics to socio-economic development and environmental indices of the 77 countries that contributed to biochar research. For this purpose, global reports and databases were evaluated for easily available, widely accepted and representative corresponding indices that reflect human development, food security and environmental circumstances (Table 1) (Lysenko et al. 2010; Steinberger et al. 2012; Organisation for Economic Cooperation and Development 2008; IPCC 2007; UNDP 2010; Sustainable Development Solutions Network 2015). Indices that reflect human development were the human development index of 2009 and its change between 2009 and 2010 (UNDP 2010), contribution of agriculture to gross domestic product in 2009 (UNSTAT, www.unstat.un.org/unsd/snaama/dnllist.asp, last update December 2013) as well as total population and its growth rate in 2009 relative to 2008 (World Bank, www. worldbank.org, 19th September 2014). Indices related to agriculture and food security were the global hunger index of 2009 (von Grebmer et al. 2013), prevalence of undernourishment (FAO, Food security indicators, www.fao.org, last update 20th December 2013), depths of the food deficit (FAO, Food security indicators, www.fao.org, last update 
Table 1 Metric indices used in this study. We included five indices related to human development, eight indices representing different aspects of agricultural performance and food security and additional eight indices indicating impact on the environment and atmosphere

\begin{tabular}{|c|c|}
\hline Topic & Index \\
\hline Human development & 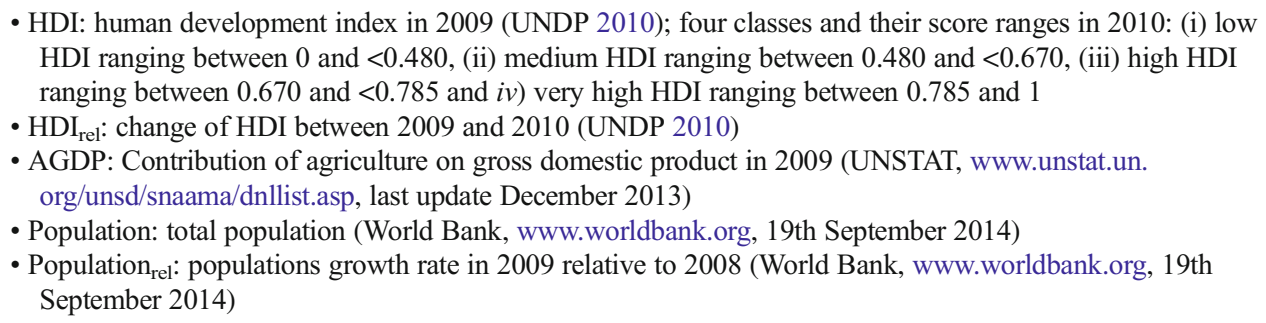 \\
\hline Agriculture and food security & $\begin{array}{l}\text { - GHI: Global hunger index in } 2009 \text { (von Grebmer et al. 2013) } \\
\text { - PoU: prevalence of undernourishment (FAO, Food security indicators, www.fao.org, last update 20th } \\
\text { December 2013) } \\
\text { - DoFD: depths of the food deficit (FAO, Food security indicators, www.fao.org, last update 20th December } \\
\text { 2013) } \\
\text { - PoFI: prevalence of food inadequacy (FAO, Food security indicators, www.fao.org, last update 20th } \\
\text { December 2013) } \\
\text { - CPC: crop land per capita (FAO 2013b); "per capita" is usually used in socio-economic sciences to indicate } \\
\text { relation to total population or per person } \\
\text { - N: N Fertilizer consumption in } 2009 \text { (FAO 2013b) } \\
\text { - P: P Fertilizer consumption in } 2009 \text { (FAO 2013b) } \\
\text { - K: K Fertilizer consumption in } 2009 \text { (FAO 2013b) }\end{array}$ \\
\hline $\begin{array}{l}\text { Environment, global warming and } \\
\text { land use intensity }\end{array}$ & $\begin{array}{l}\text { - EF: ecological footprint per capita in } 2009 \text { (Global Footprint Network 2014) } \\
\text { - BC: total bio-capacity per capita in } 2009 \text { (Global Footprint Network 2014) } \\
\text { - } \mathrm{CO}_{2} \text { AGRI: total greenhouse gas emissions from agriculture in } 2009 \text { (FAO, FAOStat Emission Database, www. } \\
\text { faostat.fao.org) } \\
\text { - } \mathrm{CO}_{2} \text { AGRI rel: relative (i.e. per capita) greenhouse gas emissions from agriculture in } 2009 \text { (FAO, FAOStat } \\
\text { Emission Database, www.faostat.fao.org) } \\
\text { - } \mathrm{CO}_{2 \mathrm{FOR}} \text { : total greenhouse gas emissions from forestry in } 2009 \text { (FAO, FAOStat Emission Database, www. } \\
\text { faostat.fao.org) } \\
\text { - } \mathrm{CO}_{2} \text { FOR rel: relative (i.e. per capita) greenhouse gas emissions from forestry in } 2009 \text { (FAO, FAOStat Emission } \\
\text { Database, www.faostat.fao.org) } \\
\text { - } \mathrm{CO}_{2 \mathrm{FFC}} \text { : total greenhouse gas emissions from fossil fuel combustion in } 2009 \text { (IEA 2013) } \\
\text { - } \mathrm{CO}_{2 \mathrm{FFC}} \text { rel: relative (i.e. per capita) greenhouse gas emissions from fossil fuel combustion in } 2009 \text { (IEA 2013) }\end{array}$ \\
\hline
\end{tabular}

20th December 2013), prevalence of food inadequacy (FAO, Food security indicators, www.fao.org, last update 20th December 2013), crop land per capita and fertilizer (i.e. N, P, K) consumption per ha in 2009 (FAO 2013b). Environmental aspects relating to global warming and land use intensity were total ecological footprint per capita (i.e. "A measure that represents the productive area required to provide the renewable resources humanity is using and to absorb its waste".) and total bio-capacity per capita (i.e. "ability of an ecosystem to produce useful biological materials and to absorb carbon dioxide"; www.footprintnetwork.org) of 2009 (Global Footprint Network 2014), and GHG emissions from individual sources of agriculture, forestry and fossil fuel combustion in 2009 (FAO, FAOStat Emission Database, www.faostat.fao.org; IEA 2013).

Since the selected country-specific indices were all descriptive and intercorrelated, an aggregation of the data into fewer factors was justified (Pavlovic and Mandel 2011). We used exploratory factor analysis to identify common, uncorrelated latent variables from the larger pool of correlated indices
(Fabrigar and Wegener 2012). This permitted us to deduce the major indicators and to find groups of relationships among these primary indicators by examining the factor loadings.

Exploratory factor analysis was applied on all indices using generalised least squares (GLS) which handles Heywood cases effectively (Jöreskog and Goldberger 1972). Heywood cases are factor estimates $>1$, which renders the factor analysis unreliable. GLS weighs the residual matrix by the inverse of the correlation matrix. This gives a greater weight to weakly correlated variables and prevents distortion of results due to collinearity of independent variables. For interpretation, the factors were rotated using VARIMAX rotation. VARIMAX rotation maximizes the variance of the loadings, which ensures that for each factor the loadings are stretched into small and high loadings (Kaiser 1958).

Based on the eigenvalues calculated by the exploratory factor analysis we chose four factors of the aggregated indices. This decision was supported by a screeplot, which displayed the eigenvalues depending on the number of factors. At the point where the eigenvalues levelled off, we determined the 
number of factors (Cattell 1966). According to the distribution of the loading values within each factor, we defined the factors as follows (Table 1, Fig. 2):

Factor 1 (Development) explained $50 \%$ of the data variability and included socio-economic and environmental indices from countries that contributed to biochar research activities (i.e. country of origin and funding by country; Table 2). This factor indicates development as shown by high loadings of (i) human development index, (ii) relative change of the human development index between 2009 and 2010, (iii) ecological footprint, (iv) contribution of agriculture to gross domestic product, (v) global hunger index, (vi) $\mathrm{CO}_{2}$ emissions from fossil fuel combustion relative to total population, (vii) population growth rate between 2008 and 2009, (viii) prevalence of undernourishment, (ix) depths of the food deficit and (x) prevalence of food inadequacy. In detail, developed countries are characterized by high human development combined with large $\mathrm{CO}_{2}$ emissions from fossil fuel combustion and a high impact on Earth's ecosystems, whereas countries, where agriculture is usually an important component of gross domestic product, are facing food scarcity and malnutrition, rapid population growth and development change.

Factor 2 ( $G H G$ emissions) explained $21 \%$ of the data variability and indicates countries with high (i) total population, (ii) total GHG emissions from agriculture and (iii) emissions from combustion of fossil fuels relative to total population. Countries having larger Factor 2 scores are for instance Brazil, China, India and the USA.

Factor 3 (Environmental resilience) explained $15 \%$ of the variability in the level of biochar research activity and indicates environmental capacity of countries to renew biotic resources used by humans and to mitigate impacts (e.g. emitted
$\mathrm{CO}_{2}$ ) as well amount of agricultural land relative to total population. As indicated by high loadings for (i) bio-capacity, (ii) crop land relative to total population and (iii) GHG emissions from agriculture relative to total population this factor is large for countries that have large areas of agricultural land causing substantial emissions of GHGs from agriculture. Countries having higher values that fit these criteria are for instance Argentina, Australia, Brazil and the USA.

Factor 4 (Intensity of agriculture) explained also 15\% of the data variability and relates to intensity of agriculture, which is indicated by high loadings for (i) $\mathrm{N}$ and (ii) $\mathrm{P}$ fertilizer use as well as by (iii) $\mathrm{CO}_{2}$ emissions from agriculture relative to total population. Countries like New Zealand, Singapore and Ireland fit these criteria and have larger values, while Australia and Canada have low values.

These factors represent country-specific indicators that relate to Development, GHG emissions, Environmental resilience and Intensity of agriculture, which were then related to common biochar research topics (see above; Atkinson et al. 2010; Sohi et al. 2010; Leach et al. 2012). Thus, aggregated socio-economic and environmental indices were used to assess relationships between biochar research topics and country-specific development and environmental quality.

\subsection{Relation between biochar research topics and aggregated environmental and socio-economic indices}

We estimated the influence of a country's socio-economic development and environmental quality for each biochar research topic (see below) and their interaction with countryspecific activities (i.e. "country of origin", "country/origin of

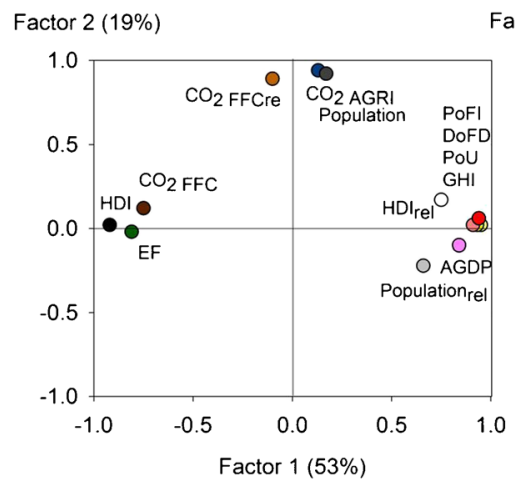

Factor $3(14 \%)$

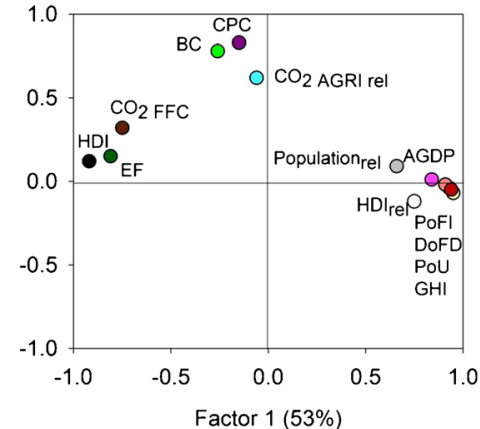

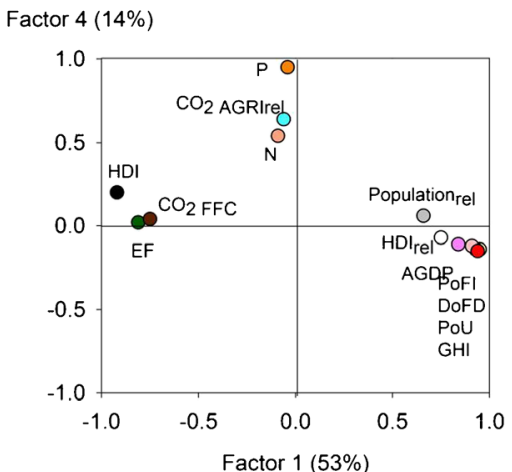

Fig. 2 Factor loading vectors showing the correlations between the socio-economic parameters obtained from global databases and datasets (Table 1), explained variance in parentheses. Values with loadings $>0.60$ are shown. HDI: human development index of 2009 (black circle) and its

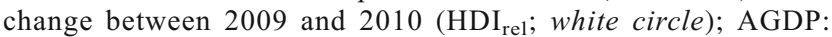
Contribution of agriculture on gross domestic product in 2009 (light purple circle); population: total population (grey circle) growth rate in 2009 relative to 2008 (population rel; light grey circle); GHI: Global hunger index of 2009 (light yellow circle); PoU: prevalence of undernourishment (yellow circle); DoFD: depths of the food dedicate (light red circle); PoFI: prevalence of food inadequacy (red circle); CPC: crop land per capita (purple circle); N: N Fertilizer consumption in 2009 (light orange circle); P: P Fertilizer consumption in 2009 (orange circle); EF: Ecological footprint per capita (green circle); BC: total biocapacity per capita of 2009 (light green circle); total and relative (i.e. per capita) greenhouse gas emissions from agriculture in $2009\left(\mathrm{CO}_{2}\right.$ AGRI, $\mathrm{CO}_{2}$ AGRI rel; blue and light blue circles); total and relative (i.e. per capita) greenhouse gas emissions fossil fuel combustion of $2009\left(\mathrm{CO}_{2}\right.$ ${ }_{\mathrm{FFC}}, \mathrm{CO}_{2} \mathrm{FFC}$ rel; brown and light brown circles) 
Table 2 Relationships between aggregated socio-economic as well as environmental indices (i.e. factors) of countries hosting and/or funding biochar research and research activities in different biochar research topics. The results shown are based on a two-step approach: (i) aggregation of 21 socio-economic and environmental indices by explanatory factor analysis to four factors (see below table footnotes;
Development, GHG emissions, Environmental resilience, Intensity of agriculture; Chapter 2.2; Table 1) and (ii) assessing the relation between these factors and biochar research activities (i.e. Chemistry \& fertility, Physics, Biology, Plant performance, GHG \& climate, Sorption, Technology) by a regression model described in Chapter 2.3. Significant relations are indicated by a "yes" and corresponding probability level

\begin{tabular}{|c|c|c|c|c|c|c|c|}
\hline Biochar research activities & Chemistry \& fertility & Physics & Biology & Plant performance & GHG \& climate & Sorption & Technology \\
\hline Factors & Country of origin & & & & & & \\
\hline Development & "yes"*** & “yes"*** & “yes”*** & “yes"** & "yes"*** & "yes"*** & "yes"*** \\
\hline GHG emissions & "yes"*** & “yes"*** & “yes”*** & "yes"*** & "yes"**** & "yes"*** & “yes"*** \\
\hline Environmental resilience & "yes"* & n.s. & “yes”*** & n.s. & "yes"*** & "yes"*** & "yes"*** \\
\hline Intensity of agriculture & n.s. & n.s. & n.s. & n.s. & n.s. & "yes"* & n.s. \\
\hline Factors & Funding by country & & & & & & \\
\hline Development & "yes"**** & "yes"*** & “yes"*** & "yes"*** & "yes"*** & "yes"*** & "yes"*** \\
\hline GHG emissions & "yes"*** & "yes"*** & “yes"*** & "yes"*** & "yes"*** & "yes"*** & "yes"*** \\
\hline Environmental resilience & n.s. & n.s. & "yes"* & n.s. & n.s. & n.s. & n.s. \\
\hline Intensity of agriculture & n.s. & n.s. & n.s. & n.s. & n.s. & n.s. & n.s. \\
\hline
\end{tabular}

Development: Factor 1 indicates country development; GHG emissions: Factor 2 relates to countries having high population and vast GHG emissions from agriculture and combustion of fossil fuels; Environmental resilience: Factor 3 indicates environmental capacity of countries to renew biotic resources used by humans and to absorb their wastes (e.g. emitted $\mathrm{CO}_{2}$ ) as well as impact of agriculture; Intensity of agriculture: Factor 4 relates to intensity of agriculture, which is indicated by high loadings for $\mathrm{N}$ and $\mathrm{P}$ fertilizer as well as by $\mathrm{CO}_{2}$ emissions per capita from agriculture

n.s. not significant

Probability level: $* * *<0.001, * *<0.01, *<0.05$

funding" and "country of institution with which authors are affiliated") with regression analysis.

Biochar research activities were grouped into seven research topics (Atkinson et al. 2010; Sohi et al. 2010). Each article addressed at least one of the following biochar research topics:

1) Effect of biochar on soil chemistry and fertility (Chemistry \& Fertility): publications that presented chemical soil properties affected by biochar additions, which reflect impacts on element cycles (i.e. C, N), nutrients (e.g. K, N, P, etc.), cation exchange capacity and soil $\mathrm{pH}$. Thus, this topic is related to soil fertility, which connects to plant nutrition and growth.

2) Effect of biochar on soil physical properties (Physics): publications that provided information of soil physical properties altered by biochar application. This topic includes effects on soil hydrology (e.g. water holding capacity, water hydraulics), soil structure (e.g. aggregation, erodibility) and energy balance (e.g. albedo).

3) Effect of biochar on soil biology (Biology): this topic includes publications that presented effects on soil biota (e.g. bacteria, fungi, earthworms) and soil enzymes.

4) Effect of biochar on plant performance (Plant performance): biochar may affect total biomass yield and mass of plant organs (e.g. root, grain). Additionally, effects on plant health and any alteration of its compositional character (e.g. proteins, sugar, nutrients) are part of this topic.
5) Biochar application to mitigate climate change and sequester carbon (GHG \& Climate): Publications that presented effects on $\mathrm{GHG}$ emissions (i.e. $\mathrm{CO}_{2}, \mathrm{CH}_{4}, \mathrm{~N}_{2} \mathrm{O}$ ) and $\mathrm{C}$-sequestration after soil application are included into this topic.

6) Biochar as a sorbent (Sorption) of organic and inorganic compounds: Here we included publications that studied or reviewed effects on inorganic and organic soil compounds (e.g. retention, immobilization, degradation).

7) Biochar production and economic assessment (Technology): This topic covers publications that presented technologies to produce modified and treated biochars. Formation and handling of biochar may also affect economic aspects, thus, this topic also included in the category of biochar production and economic assessments. This meta-analysis, however, considered only publications that presented technologies to produce modified and treated biochars without further assessments to prevent repetition of research (see also section 1).

The response of the regression model (i.e. the number of publications within the specific research topic) was related to the extracted factor scores from the exploratory factor analysis. Since the response variable is the counted number of publications, we used a general linear model coupled to a logistic link function and a Poisson distributed error structure (Crawley 2002). Some of the general linear models experienced over-dispersion as assessed by the test of Cameron 
and Trivedi (2005); this might eventually underestimate the standard errors of the coefficients and thus overestimate the statistical significance of the factors (Fitzmaurice 1997). In the case of overdispersion, a negative binomial general linear model with full maximum likelihood estimation was applied (Hilbe and Robinson 2013; Venables and Ripley 2003).

\section{Results and discussion}

We identified and screened a total number of 1250 publications (i.e. research papers, reviews, short communications and notes) to assess relations between biochar research topics and overall indicators derived from 21 country-specific socio-economic and environmental indices. Sources of funding were mentioned in 1010 publications (81\%). In 474 publications (38\%), authors were from countries in a development status lower than "very highly developed" (Table 2; UNDP 2010). Due to multiple entries for experiments that (i) were performed in multiple countries, (ii) were supported by multiple funders or (iii) were written by authors from multiple countries, the final dataset consists of 1430 observations (i.e. rows). Most research associated with countries with a less development score (i.e. low and medium human development) was performed to study biochar production and to do economic assessments accounting $27 \pm 1 \%$ of all research activities in these countries. Another focus of biochar research in less developed countries was the study of impact of biochar on chemistry \& fertility and plant performance, which accounted for $19 \pm 1 \%$ and $17 \pm 3 \%$ of total research activities, respectively. Less research was recorded for $G H G \&$ climate $(15 \pm 1 \%)$, sorption $(15 \pm 2 \%)$ and biology $(6 \pm 1 \%)$. Very little research was performed to assess effects of biochar on soil physics accounting for only $2 \pm 1 \%$ of the total research activities, which might be a result of slow soil formation processes (e.g. formation of soil aggregates) and/or capabilities required to assess them (Ajayi and Horn 2016; Obia et al. 2016).

Biochar research is anticipated to support climate-smart agriculture, food security and livelihoods for poor farmers (Leach et al. 2012; FAO 2013a), but effectiveness has not been conclusively and systematically assessed. Linking all 21 indices to biochar research activities is a promising way to test whether socio-economic development and environmental quality interact to determine biochar research activities. Our findings revealed that global biochar research activities differed among countries depending on their level of development and their $G H G$ emissions (see above and Table 2, Fig. 3). As country development and GHG emission levels increased so did research activity and funding for all biochar research topics mentioned above (Table 2) and illustrated in Fig. 3 for the most popular biochar research topics: chemistry \& fertility (i.e. $18 \pm 1 \%$ ) and technology $(30 \pm 0 \%)$. Environmental resilience and impact of agriculture correlated with a few biochar research topics
(Table 2). For biology both data sets revealed a correlation with the countries' environmental resilience, while further correlations were found exclusively for the "Country of origin" dataset.

\subsection{Influence of development on biochar research}

The most important factor 1 in this analysis (Development) correlated strongly with all biochar research topics (Fig. 2, Table 2). The individual factor scores of the countries in this dataset correlated (i.e. Spearman) strongly with the human development index (Table 1; $P<0.05 ; R=-0.83$ ). Hence, the widely accepted and commonly used human development index was used in this study to assess the relation between human development and biochar research activities.

Countries low on the human development index (Table 1; UNDP 2010) undertook biochar research in four areas: chemistry \& fertility (24\%), plant performance (22\%), GHG \& climate (27\%) and technology (27\%). Similarly, surveyed funding activities revealed an intense support of biochar research on chemistry \& fertility (22\%), plant performance (33\%), GHG \& climate (22\%) and technology (22\%), but just $1.1 \%$ of mentioned funding sources originated from countries low on the human development index. Only three publications mentioned funding from countries with low human development index (Table 1; Ali et al. 2012; Deal et al. 2012; Sparrevik et al. 2013; UNDP 2010). Each of these three studies was devoted to the area of plant performance and 2 of the 3 assessed also effects on chemistry \& fertility, $G H G \&$ climate and technology. Thus, the majority ( $\sim 99 \%)$ of surveyed funding originated from funding sources in highly developed countries (HDI > 0.480; UNDP 2010). Limited funding from countries with low human development index scores may be the result of limited financial resources (Delmer 2005). Therefore, a small number of studies were published, but they revealed that low developed countries focused on assessing potential use of biochar to improve agronomic production as reflected by large proportion of studies related to the research topics chemistry \& fertility and plant performance. This interest probably relates to findings reporting that biochar can increase biomass and crop yields especially on low fertility soils in the tropics, which are common in developing tropical countries (Crane-Droesch et al. 2013; Glaser et al. 2002; Liu et al. 2013; Barrett and Bevis 2015; Cornelissen et al. 2013; Obia et al. 2016). Therefore, developing countries in the tropics suffering from hunger and poverty supported biochar research with the aim to increase agronomic productivity (Barrett and Bevis 2015; Folberth et al. 2016; Mueller et al. 2012), which clearly links to the zero hunger and reducing poverty Sustainable Development Goals (UN 2015).

Biochar research topics in countries ranked medium on the human development index (Table 1; UNDP 2010) differed to those of low development countries due to higher interest in the topics sorption $(27 \pm 0 \%)$ and technology $(28 \pm 1 \%)$ 
Fig. 3 Biochar research activities on chemistry \& fertility and technology in terms of total number of publications and their relation to the countries' development (i.e. larger number implies higher development) and their GHG emissions (i.e. larger number implies higher impact on GHG emissions) (see also Table 2)

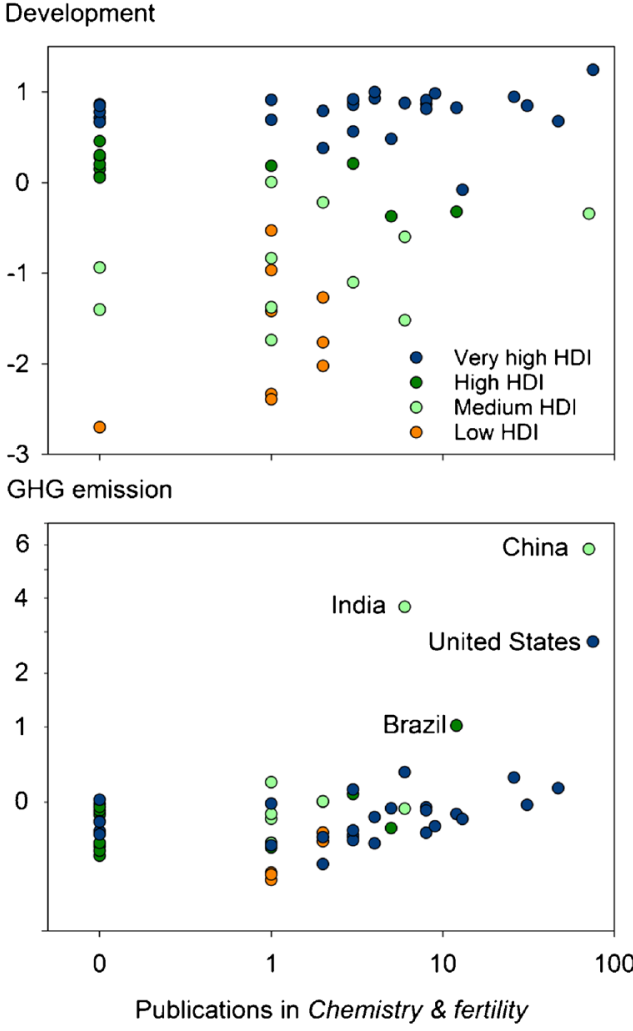

Development

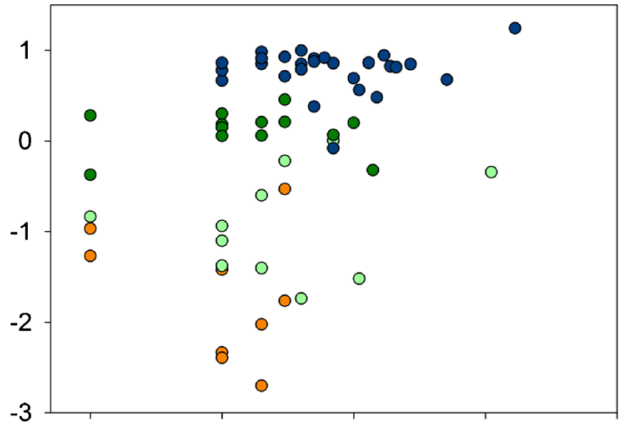

GHG emission

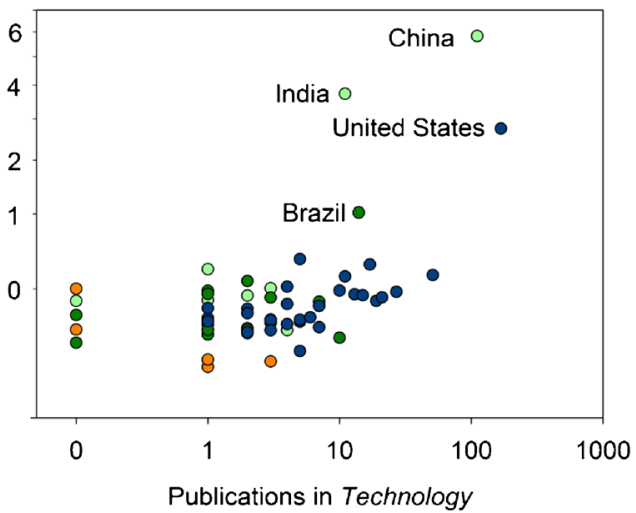

compared to lower interest in chemistry \& fertility $(15 \pm 2 \%)$ and plant performance $(10 \pm 0 \%)$. It is interesting to note that biochar research activities and funding for countries with a medium human development index score were dominated by Chinese research and funding activities, ranging between 75 and 95\% among all research topics (Figs. 4 and 5). Between 2010 and 2014 China's contribution to biochar research increased continuously and more strongly than in other countries with intermediate development scores (Fig. 5). Especially, the latter reflects efforts by China to protect the environment and to restore degraded/polluted land (Zhang et al. 2016; Albert and Xu 2014) using biochar (Kong et al. 2014; Ahmad et al. 2014; Zhang et al. 2013). Other countries in this group (e.g. India, Pakistan and South Africa) focused their research on chemistry $\&$ fertility $(16 \pm 2 \%)$ and technology $(36 \pm 3 \%)$, and to a lesser extent on plant productivity (14 $\pm 0 \%$ ) (Fig. 4). Their research activities often combined aims of sustainable food and energy production while assessing potential use of secondary resources (e.g. organic wastes) (Saranya et al. 2011; Singh and Sidhu 2014; Liu et al. 2014; Naeem et al. 2014; Bolan et al. 2013). It is important that wastes are free of contaminates to prevent any negative impact on the environment and food chain (Kookana et al. 2011; Kusmierz and Oleszczuk 2014; Lucchini et al. 2014).

Although authors from 21 countries with development scores lower than high (i.e. HDI < 0.670; UNDP 2010) conducted research on biochar, their output in form of publications was low relative to countries having high and very high human development. Publications prepared entirely by authors associated to institutions in countries with a human development index of $<0.670$ was low (18\%), but it clearly indicates a successful scientific South-South cooperation due to collaboration among these countries (e.g. Demisie et al. 2014; Ibrahim et al. 2013; Zhang et al. 2012). Similarly, contribution of mixed groups (i.e. North-South cooperation) was also low, accounting for only $15 \%$ of all publications (e.g. Deenik et al. 2011; Deal et al. 2012; Nelissen et al. 2014; Ahmad et al. 2013), while contribution of authors linked to institutions in countries with high and very high human development index was very high accounting for $67 \%$ of the published research. The enormous body of literature produced by countries with high and specifically with very high Human Development Indices covers all biochar research topics mentioned above (Figs. 4 and 5). However, the majority of supported and conducted research assessed effects on chemistry \& fertility $(18 \pm 1 \%)$ and technology $(34 \pm 1 \%)$. These countries also did research on biology $(10 \pm 1 \%)$, plant performance $(11 \pm 0 \%), G H G$ \& climate $(13 \pm 1 \%)$, and sorption $(12 \pm 0 \%)$. In addition, research was done to study the effects of biochar on soil physics $(3 \pm 1 \%)$. The higher the countries' human development score, the higher was the diversity of biochar research topics and outputs, which is crucial to develop sustainable strategies to improve plant productivity and adaptation to climate change (FAO 2013a; Bouma 2014). Thus, biochar research activities in highly developed countries were more intense, 
2010 to 2014

Number of publications / \%

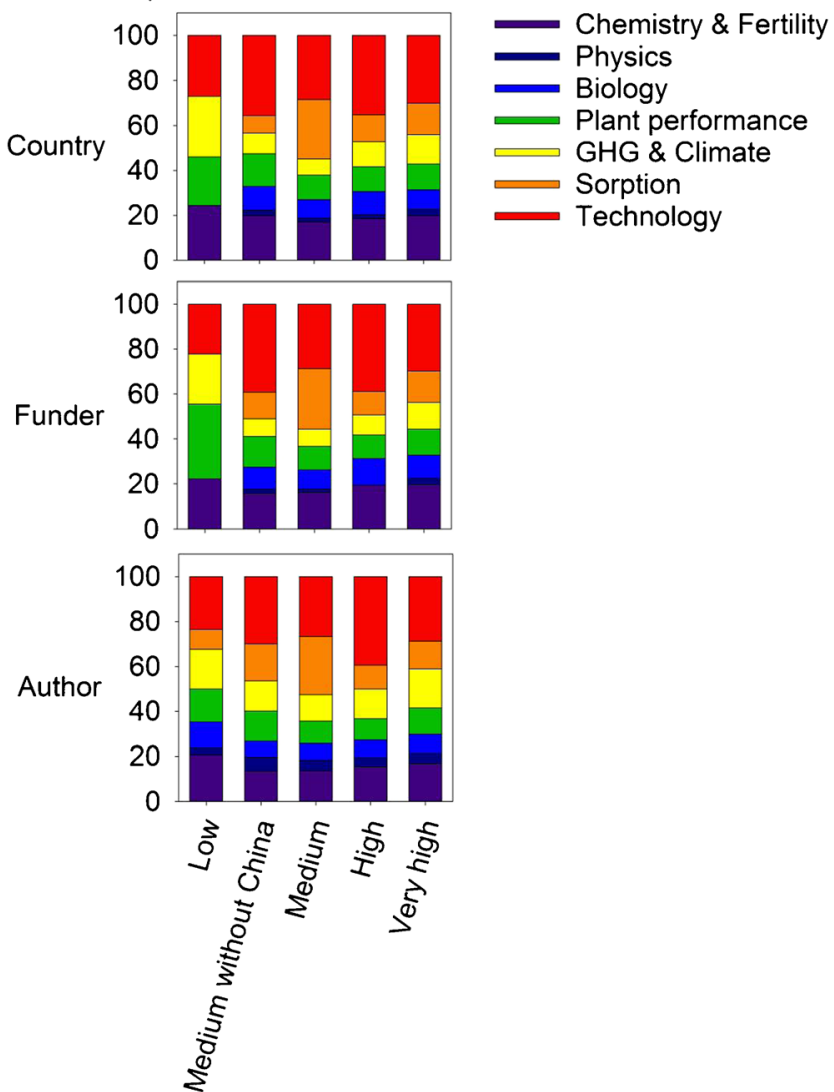

Fig. 4 Biochar research related publication activity in 2010 to 2014 sorted by biochar research topics (see Material \& Methods section) and research country, funding country and author's country (i.e. their affiliation). Research topics were assessed and sorted in accordance to the countries' human development index of 2009 (Table 1); low human development $<0.480$, medium human development $<0.670$, high human development $<0.785$ and very high human development ranges between 0.785 and 1 (UNDP 2010)

diverse, and due to overlapping activities, more complex than in low and medium developed countries.

Das (2015), OECD (2012), and Pietrobelli and Rabellotti (2011) explained low or even lacking acquisition of new technologies and innovations in developing countries by the following factors: (i) lacking diversity of research actors (i.e. governmental and higher education sector $>>$ business enterprise sector); (ii) inadequate research infrastructure and weak interaction with the local business enterprise sector; and (iii) lack of knowledge, equipment, human and financial resources. However, developing sustainable growth strategies (e.g. climate-smart agriculture combined with biochar) requires removing existing knowledge gaps, capacity and policy barriers by (i) establishing reliable technology transfer/translation, capacity building, funding mechanisms and (ii) promoting local research and interaction between research actors by improving research policy, education and research infrastructure (Dinesh et al. 2016; Delmer 2005; Calderón and Fuentes 2012; Garb and
Friedlander 2014). Evidently, biochar research coordinated and conducted by research groups from highly developed countries (e.g. Australia, Norway, USA) has already produced a huge body of knowledge on how biochar affects soil properties and plant productivity in the sub-tropics and tropics (Macdonald et al. 2014; Cornelissen et al. 2013; Novak et al. 2009). Thus, effort is now required to transfer/translate biochar knowledge, to change behaviour and encourage implementation of agricultural biochar strategies in the tropics.

\subsection{Influence of GHG emission on biochar research}

This analysis shows that countries that are large primary producers of agricultural products (i.e. Brazil, China, India and USA; Fig. 3) are interested in offsetting and reducing greenhouse gas emission from agriculture by using biochar (FAO 2012; Laird 2008; IPCC 2000; Cayuela et al. 2010; Mukherjee and Lal 2013). Notably, these four countries emitted in 2009 about $51 \%$ (i.e. Brazil $10 \%$, India $15 \%$, China $19 \%$ and USA $9 \%$ ) of total GHG emissions from agriculture (FAO, FAOStat Emission Database, www.faostat.fao.org; Table 1) from the 77 countries assessed in this study. Additionally, Brazil and the USA produced large quantities of GHGs from combustion of fossil fuels (IEA 2013), which were large even when expressed in per capita terms (Brazil: $12.5 \mathrm{Mg} \mathrm{CO}_{2}$ capita $^{-1}$, USA: $16.9 \mathrm{Mg} \mathrm{CO}_{2}$ capita $^{-}$ $\left.{ }^{1}\right)$. Relative emission from fossil fuel combustion in India (1. $4 \mathrm{Mg} \mathrm{CO}_{2}$ capita $^{-1}$ ) and China $\left(5.1 \mathrm{Mg} \mathrm{CO}_{2}\right.$ capita $^{-1}$ ) was in the middle of the data utilized, ranging between 1.3 and $8.5 \mathrm{Mg}$ $\mathrm{CO}_{2}$ capita $^{-1}$ (IEA 2013). Reducing emissions from fossil fuel combustion and agriculture is a global task and requires contributions from all countries to mitigate climate change, and to adapt the energy sector and land use (i.e. agriculture and forestry) to the changing climate (FAO 2009; IPCC 2000, 2013; Hallegatte et al. 2016). Recently, Wollenberg et al. (2016) stated that agriculture can contribute to the $2{ }^{\circ} \mathrm{C}$ target for limiting global warming, but reliable strategies and technologies are required to manage, e.g. agricultural emissions of $\mathrm{CH}_{4}$ and $\mathrm{N}_{2} \mathrm{O}$ (IPCC 2013). Although it is clear that biochar can reduce emissions of GHGs (Cayuela et al. 2014; Borchard et al. 2014c), stabilize labile organic matter (Borchard et al. 2014a) and remain in agricultural soils for at least decades (Preston and Schmidt 2006; Borchard et al. 2014b) contradictory findings (Wardle et al. 2008; Borchard et al. 2014c; Zimmermann et al. 2012) elucidate needs to assess mechanisms controlling GHG emissions in more detail across varying environments and climatic zones (Schmidt et al. 2011).

\subsection{Influence of environmental resilience and agriculture on biochar research}

Assessing relations between both the countries' environmental resilience and impact of agriculture to the biochar research activities revealed an inconsistency between location of research 
Chemistry \& Fertility Physics

Biology

Plant performance GHG \& Climate

Sorption

Technology

Number of publications / $\%$
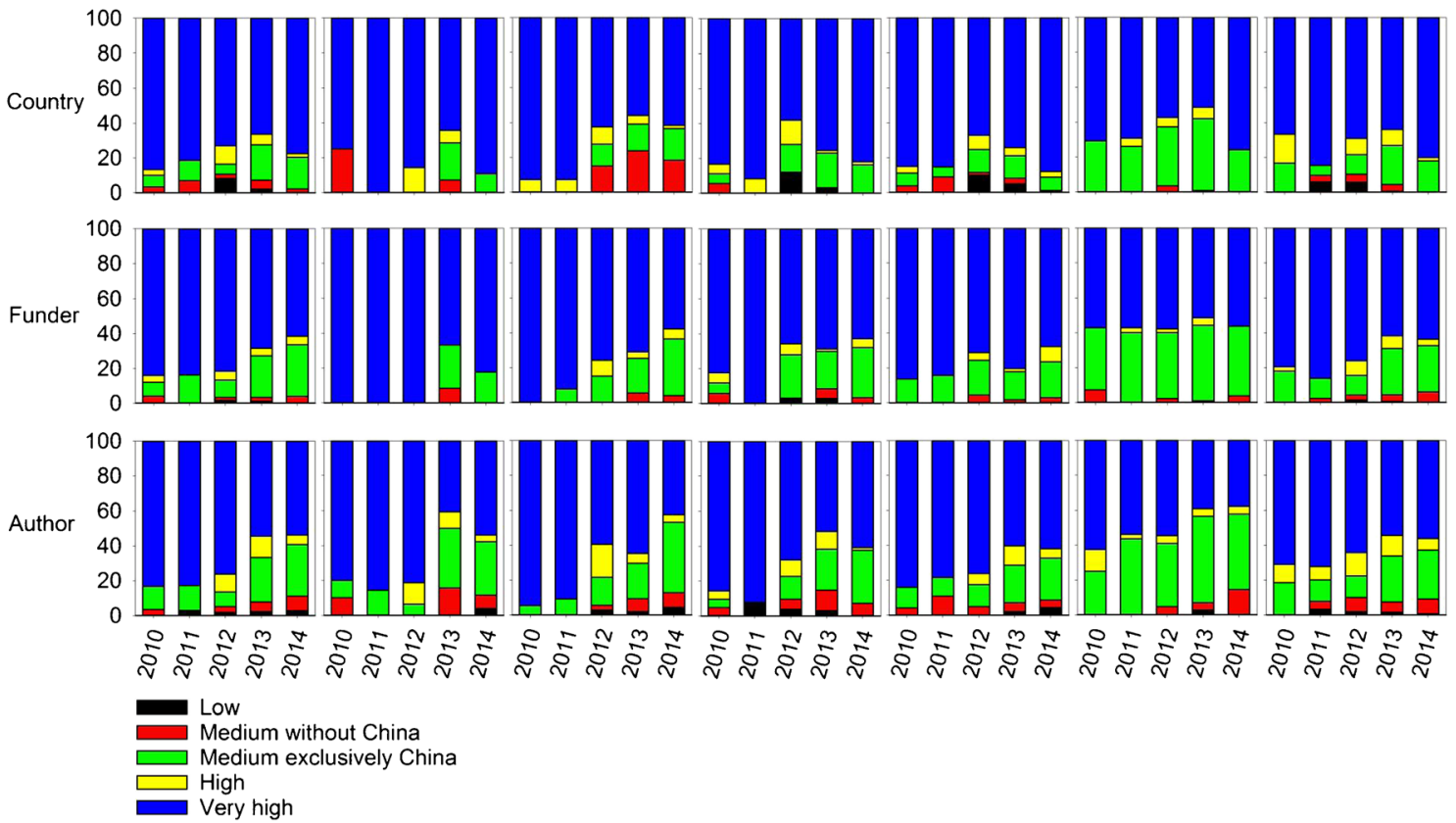

Fig. 5 Biochar research related publication activity for each year in 2010 to 2014 sorted by biochar research topics (see Material \& Methods section), research country, funding country and author's country (i.e. their affiliation). Research topics were assessed and sorted in

accordance to the countries' human development index of 2009 (Table 1); low human development $<0.480$, medium human development $<0.670$, high human development $<0.785$ and very high human development ranges between 0.785 and 1 (UNDP 2010)

(i.e. country of origin) and funding by country (Table 2). A smaller number of acknowledged funding resources may explain non-significant relations between funding sources from countries scored by their environmental resilience and impact of agriculture to almost all biochar research topics. Countries with high scores for environmental resilience and areas with very low population densities (Argentina, Australia, Brazil, Canada, and New Zealand) hosted research assessed impact of biochar on chemistry \& fertility, GHG \& climate, sorption and technology (Table 2 "Country of origin"). The countries' interest in assessing impacts of biochar on these issues can be related to their efforts to improve soil fertility, to sequester carbon and to use pesticides efficiently in agriculture (Kookana 2010; Blackwell et al. 2010; Jablonowski et al. 2012). Assessing effects of biochar on soil biota was clearly related to the countries' environmental resilience as reflected by significant relations to the country of origin and funding (Table 2) and their ability to promote and facilitate biological research that required more sophisticated methods and equipment (Delmer 2005).

\section{Conclusion and implication for future activities}

This meta-analysis presents for the first time results on global biochar research activities and their relation to socio-economic development of the countries hosting/funding the research. Biochar research activities are concentrated in very highly

developed countries, with little effort in poor tropical countries. However, those countries in which poor soils are abundant may benefit substantially from agricultural innovations that include biochar (Crane-Droesch et al. 2013; Barrett and Bevis 2015; FAO 2013a). Further, the lack of research being done in poor tropical countries may result in researchers missing local and indigenous innovations that could enhance biochar efficacy where it is most needed (van Vliet et al. 2012; Nigh and Diemont 2013; Miltner and Coomes 2015). Thus, to realize the potential benefits of biochar in poor tropical countries we need cooperation (e.g. interdisciplinary research, knowledge transfer/translation) and investments (e.g. research equipment and infrastructure) in countries that are interested in doing integrated research that includes biochar as a tool to improve crop productivity and to mitigate climate change (Calderón and Fuentes 2012; Das 2015; Garb and Friedlander 2014). Biochar research activities can contribute substantially to the $2{ }^{\circ} \mathrm{C}$ target for limiting global warming (Wollenberg et al. 2016; FAO 2013a; Leach et al. 2012). Further global efforts in biochar research are required to understand and manage nutrient dynamics and impacts on GHG emissions. Therefore, based on the results of this review, we identify the following research priorities to assess and promote the role of biochar in development of adapted and sustainable agronomic methods:

1. Intensify transfer/translation of existing knowledge, and capacity building required to conduct climate-smart agronomic research across countries of different development

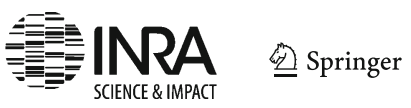


levels. It is important to educate and train local experts in science, policy and best-practice examples (e.g. Schmidt et al. 2015) to ensure effective research and successful implementation of new technologies and methods including biochar in poor tropical countries.

2. Enhance research investments and technical cooperation used to conduct agronomic research across countries of different development levels. In developing countries, research is often limited to simple (and often labourintensive) objectives (e.g. plant growth, but not plant physiology) restricting depth and complexity of their biochar research activities. However, to understand the complex interactions among biochar, soil and plants, and to develop methods applicable for end-users, a mixture of simple and high-tech methods is required and has been initiated recently by research networks (e.g. the Biochar for Sustainable Soils project [http://biochar.international//]).

3. Sustainable and climate-smart agriculture using biochar needs knowledge about soil chemistry and plant productivity that is required to manage nutrient application. However, soil biology and physical properties are also drivers that affect nutrient and water availability and thus plant productivity. Therefore, agronomic research using and managing soil biology and physics to enhance plant productivity are needed, but rarely performed.

4. Finally, agronomic research must be interdisciplinary to ensure greatest benefit from soil and biochar research. Cooperation among several scientific disciplines (e.g. plant science, soil science, and hydrology) is required to facilitate development of sustainable agronomic methods.

\begin{abstract}
Acknowledgments Financial support was received by the multilateral Joint Programming Initiative on "Agriculture, Food security and Climate Change (FACCE-JPI), subtopic Agricultural Greenhouse Gas Research. Jose M. Estavillo and Teresa Fuertes-Mendizabal belong to the Basque Government IT-932-16 research group. Nils Borchard was placed as integrated expert by the Centre for International Migration and Development (CIM). CIM is a joint operation of the Deutsche Gesellschaft für Internationale Zusammenarbeit (GIZ) $\mathrm{GmbH}$ and the International Placement Services (ZAV) of the German Federal Employment Agency (BA). Claudia Kammann gratefully acknowledges DFG grant KA3442/1-1 enabling her to continue biochar work. ML Cayuela thanks Fundación Séneca (19281/PI/14).
\end{abstract}

Open Access This article is distributed under the terms of the Creative Commons Attribution 4.0 International License (http:// creativecommons.org/licenses/by/4.0/), which permits unrestricted use, distribution, and reproduction in any medium, provided you give appropriate credit to the original author(s) and the source, provide a link to the Creative Commons license, and indicate if changes were made.

\section{References}

Ahmad M, Lee SS, Rajapaksha AU, Vithanage M, Zhang M, Cho JS, Lee S-E, Ok YS (2013) Trichloroethylene adsorption by pine needle biochars produced at various pyrolysis temperatures. Bioresour Technol 143:615-622. doi:10.1016/j.biortech.2013.06.033
Ahmad M, Rajapaksha AU, Lim JE, Zhang M, Bolan N, Mohan D, Vithanage M, Lee SS, Ok YS (2014) Biochar as a sorbent for contaminant management in soil and water: a review. Chemosphere 99: 19-33. doi:10.1016/j.chemosphere.2013.10.071

Ajayi AE, Horn R (2016) Modification of chemical and hydrophysical properties of two texturally differentiated soils due to varying magnitudes of added biochar. Soil Tillage Res. doi:10.1016/j.still.2016. 01.011

Albert E, Xu B (2014) China's environmental crisis. Council on Foreign Relations. http://www.cfr.org/china/chinas-environmental-crisis/ p12608. Accessed 15 Sept 2016

Ali MA, Hoque MA, Kim PJ (2012) Mitigating global warming potentials of methane and nitrous oxide gases from rice paddies under different irrigation regimes. Ambio 42(3):357-368. doi:10.1007/ s13280-012-0349-3

Atkinson CJ, Fitzgerald JD, Hipps NA (2010) Potential mechanisms for achieving agricultural benefits from biochar application to temperate soils: a review. Plant Soil 337(1-2):1-18. doi:10.1007/s11104-0100464-5

Barman D, Mandal SC, Pampa B, Nandita R (2013) Land degradation: its control, management and environmental benefits of management in reference to agriculture and aquaculture. Environ Ecol 31(2C): $1095-1103$

Barrett CB, Bevis LEM (2015) The self-reinforcing feedback between low soil fertility and chronic poverty. Nat Geosci 8(12):907-912. doi:10.1038/ngeo2591

Blackwell P, Krull E, Butler G, Herbert A, Solaiman Z (2010) Effect of banded biochar on dryland wheat production and fertiliser use in south-western Australia: an agronomic and economic perspective. Soil Research 48(7):531-545. doi:10.1071/SR10014

Bolan NS, Kunhikrishnan A, Naidu R (2013) Carbon storage in a heavy clay soil landfill site after biosolid application. Sci Total Environ 465:216-225. doi:10.1016/j.scitotenv.2012.12.093

Borchard N, Ladd B, Eschemann S, Hegenberg D, Möseler BM, Amelung W (2014a) Black carbon and soil properties at historical charcoal production sites in Germany. Geoderma 232-234(0):236242. doi:10.1016/j.geoderma.2014.05.007

Borchard N, Siemens J, Ladd B, Möller A, Amelung W (2014b) Application of biochars to sandy and silty soil failed to increase maize yield under common agricultural practice. Soil Tillage Res 144(0):184-194. doi:10.1016/j.still.2014.07.016

Borchard N, Spokas K, Prost K, Siemens J (2014c) Greenhouse gas production in mixtures of soil with composted and noncomposted biochars is governed by char-associated organic compounds. J Environ Qual 3:971-979. doi:10.2134/jeq2013.07.0290

Bouma J (2014) Soil science contributions towards sustainable development goals and their implementation: linking soil functions with ecosystem services. J Plant Nutr Soil Sci 177(2):111-120. doi:10. 1002/jpln.201300646

Calderón C, Fuentes JR (2012) Removing the constraints for growth: some guidelines. J Policy Model 34(6):948-970. doi:10.1016/j. jpolmod.2012.04.007

Cameron AC, Trivedi PK (2005) Microeconometrics: methods and applications. Cambridge University Press, Cambridge

Cattell RB (1966) The screen test for the number of factors. Multivar Behav Res 1(2):245-276. doi:10.1207/s15327906mbr0102 10

Cayuela M, Oenema O, Kuikman P, Bakker R, Van Groenigen J (2010) Bioenergy by-products as soil amendments? Implications for carbon sequestration and greenhouse gas emissions. Global Change Biology Bioenergy 2(4):201-213. doi:10.1111/j.1757-1707.2010. 01055.x

Cayuela ML, van Zwieten L, Singh BP, Jeffery S, Roig A, SánchezMonedero MA (2014) Biochar's role in mitigating soil nitrous oxide emissions: a review and meta-analysis. Agric Ecosyst Environ 191(15):5-16. doi:10.1016/j.agee.2013.10.009 
Cornelissen G, Martinsen V, Shitumbanuma V, Alling V, Breedveld DG, Rutherford WD, Sparrevik M, Hale ES, Obia A, Mulder J (2013) Biochar effect on maize yield and soil characteristics in five conservation farming sites in Zambia. Agronomy 3(2). doi:10.3390/ agronomy 3020256

Crane-Droesch A, Abiven S, Jeffery S, Torn MS (2013) Heterogeneous global crop yield response to biochar: a meta-regression analysis. Environ Res Lett 8(4). doi:10.1088/1748-9326/8/4/044049

Crawley MJ (2002) Statistical computing: an introduction to data analysis using S-Plus. Wiley, Chichester

Das GG (2015) Why some countries are slow in acquiring new technologies? A model of trade-led diffusion and absorption. J Policy Model 37(1):65-91. doi:10.1016/j.jpolmod.2015.01.001

Deal C, Brewer CE, Brown RC, Okure MAE, Amoding A (2012) Comparison of kiln-derived and gasifier-derived biochars as soil amendments in the humid tropics. Biomass Bioenergy 37:161168. doi:10.1016/j.agee.2013.10.009

Deenik JL, Diarra A, Uehara G, Campbell S, Sumiyoshi Y, Antal MJ Jr (2011) Charcoal ash and volatile matter effects on soil properties and plant growth in an acid Ultisol. Soil Sci 176(7). doi:10.1097/SS. 0b013e31821fbfea

Delmer DP (2005) Agriculture in the developing world: connecting innovations in plant research to downstream applications. Proc Natl Acad Sci U S A 102(44):15739-15746. doi:10.1073/pnas. 0505895102

Demisie W, Liu Z, Zhang M (2014) Effect of biochar on carbon fractions and enzyme activity of red soil. Catena 121:214-221. doi:10.1016/j. catena.2014.05.020

Dinesh D, Vermeulen S, Bacudo I, Martinez-Baron D, Castro-Nunez A, Hedger M, Huyer S, Iversen P, Laure A, Loboguerrero Rodriguez AM, Martius C, Neufeldt H, Nyasimi M, Richards M, Wollenberg L (2016) Options for agriculture at Marrakech climate talks: messages for SBSTA 45 agriculture negotiators. CCAFS report, vol 16. CGIAR Research Program on Climate Change, Agriculture and Food Security (CCAFS), Copenhagen

Enders A, Hanley K, Whitman T, Joseph S, Lehmann J (2012) Characterization of biochars to evaluate recalcitrance and agronomic performance. Bioresour Technol. doi:10.1016/j.biortech.2012.03. 022

Fabrigar LR, Wegener DT (2012) Exploratory factor analysis. Understanding statistics. Oxford University Press, New York

FAO (2009) Food security and agricultural mitigation in developing countries: options for capturing synergies. Food and Agriculture Organization of the United Nations (FAO), Rome

FAO (2012) Statistical yearbook 2012: World food and agriculture. Rome

FAO (2013a) Climate-smart agriculture: sourcebook. Food and Agriculture Organization of the United Nations (FAO), Rome

FAO (2013b) FAO Statistical Yearbook 2013 — world food and agriculture. FAO Statistical Yearbooks. Food and Agriculture Organization of the United Nations (FAO), Rome

Fitzmaurice GM (1997) Model selection with overdispersed data. Journal of the Royal Statistical Society: Series D (The Statistician) 46(1): 81-91. doi:10.1111/1467-9884.00061

Folberth C, Skalsky R, Moltchanova E, Balkovic J, Azevedo LB, Obersteiner M, van der Velde M (2016) Uncertainty in soil data can outweigh climate impact signals in global crop yield simulations. Nat Commun 7. doi:10.1038/ncomms 11872

Garb Y, Friedlander L (2014) From transfer to translation: using systemic understandings of technology to understand drip irrigation uptake. Agric Syst 128:13-24. doi:10.1016/j.agsy.2014.04.003

Gattinger A, Muller A, Haeni M, Skinner C, Fliessbach A, Buchmann N, Mäder P, Stolze M, Smith P, Scialabba NE-H, Niggli U (2012) Enhanced top soil carbon stocks under organic farming. Proc Natl Acad Sci U S A 109(44):18226-18231. doi:10.1073/pnas. 1209429109
Glaser B, Lehmann J, Zech W (2002) Ameliorating physical and chemical properties of highly weathered soils in the tropics with charcoal - a review. Biol Fertility Soils 35(4):219-230. doi:10.1007/ s00374-002-0466-4

Global Footprint Network (2014) National footpring accounts of the year 2009. Available online at http://www.footprintnetwork.org

Godfray HCJ, Beddington JR, Crute IR, Haddad L, Lawrence D, Muir JF, Pretty J, Robinson S, Thomas SM, Toulmin C (2010) Food security: the challenge of feeding 9 billion people. Science 327(5967):812818. doi:10.1126/science.1185383

Gregory PJ, Ingram JSI, Brklacich M (2005) Climate change and food security. Philosophical Transactions of the Royal Society of London B: Biological Sciences 360(1463):2139-2148. doi:10.1098/rstb. 2005.1745

Gurwick NP, Moore LA, Kelly C, Elias P (2013) A systematic review of biochar research, with a focus on its stability in situ and its promise as a climate mitigation strategy. Public Library of Science One 8(9): e75932. doi:10.1371/journal.pone.0075932

Haider G, Steffens D, Müller C, Kammann CI (2016) Standard extraction methods may underestimate nitrate stocks captured by field-aged biochar. J Environ Qual 45:1196-1204. doi:10.2134/jeq2015.10. 0529

Hallegatte S, Rogelj J, Allen M, Clarke L, Edenhofer O, Field CB, Friedlingstein P, van Kesteren L, Knutti R, Mach KJ, Mastrandrea M, Michel A, Minx J, Oppenheimer M, Plattner G-K, Riahi K, Schaeffer M, Stocker TF, van Vuuren DP (2016) Mapping the climate change challenge. Nat Clim Chang 6(7):663-668. doi:10. 1038/nclimate3057

Hernández-Soriano MC, Kerré B, Goos P, Hardy B, Dufey J, Smolders E (2015) Long-term effect of biochar on the stabilization of recent carbon: soils with historical inputs of charcoal. Global Change Biology Bioenergy 8(2):371-381. doi:10.1111/gcbb.12250

Hilbe JM, Robinson AP (2013) Methods of statistical model estimation. CRC Press, Boca Raton

Ibrahim HM, Al-Wabel MI, Usman ARA, Al-Omran A (2013) Effect of conocarpus biochar application on the hydraulic properties of a sandy loam soil. Soil Sci 178(4). doi:10.1097/SS. 0b013e3182979eac

IEA (2013) CO2 emissions from fuel combustion 2013. International Energy Agency, Paris. doi:10.1787/co2_fuel-2013-en

Initiative ELD (2015) The value of land: prospectous lands and positive rewards through sustainable land management. ELD Secretariat, Bonn

IPCC (2000) Land use, land-use change and forestry. Cambridge University Press, UK; Intergovernmental Panel on Climate Change (IPCC), Cambridge

IPCC (2007) Climate Change 2007: mitigation of climate change. Contribution of working group III to the fourth assessment report of the Intergovernmental Panel on Climate Change (IPCC). Cambridge and New York

IPCC (2013) Climate Change 2013: the physical science basis. Contribution of working group I to the fifth assessment report of the Intergovernmental Panel on Climate Change. Intergovernmental Panel on Climate Change (IPCC), Cambridge and New York

Jablonowski ND, Borchard N, Zajkoska P, Fernández-Bayo JD, Martinazzo R, Berns AE, Burauel P (2012) Biochar-mediated 14C-atrazine mineralization in atrazine-adapted soils from Belgium and Brazil. J Agric Food Chem 61(3):512-516. doi:10. 1021/jf303957a

Jeffery S, Verheijen FGA, van der Velde M, Bastos AC (2011) A quantitative review of the effects of biochar application to soils on crop productivity using meta-analysis. Agric Ecosyst Environ 144(1): 175-187. doi:10.1016/j.agee.2011.08.015

Jennions MD, Lortie CJ, Rosenberg MS, Rothstein HR (2013) Publication and related bias. In: Koricheva J, Gurevitch J, Mengersen K (eds) 
Handbook of meta-analysis in ecology and evolution. Princeton University Press, Princeton and Oxford, pp 207-236

Jie C, Jing-zhang C, Man-zhi T, Zi-tong G (2002) Soil degradation: a global problem endangering sustainable development. J Geogr Sci 12(2):243-252. doi:10.1007/BF02837480

Jöreskog K, Goldberger A (1972) Factor analysis by generalized least squares. Psychometrika 37(3):243-260. doi:10.1007/BF02306782

Joseph S, Graber ER, Chia C, Munroe P, Donne S, Thomas T, Nielsen S, Marjo C, Rutlidge H, Pan GX, Li L, Taylor P, Rawal A, Hook J (2013) Shifting paradigms: development of high-efficiency biochar fertilizers based on nano-structures and soluble components. Carbon Management 4(3):323-343. doi:10.4155/cmt.13.23

Kaiser HF (1958) The varimax criterion for analytic rotation in factor analysis. Psychometrika 23(3):187-200. doi:10.1007/BF02289233

Kammann CI, Schmidt H-P, Messerschmidt N, Linsel S, Steffens D, Müller C, Koyro H-W, Conte P, Joseph S (2015) Plant growth improvement mediated by nitrate capture in co-composted biochar. Scientific Reports 5:11080. doi:10.1038/srep11080

Keiluweit M, Nico PS, Johnson MG, Kleber M (2010) Dynamic molecular structure of plant biomass-derived black carbon (biochar). Environ Sci Technol 44(4):1247-1253. doi:10.1021/es9031419

Kögel-Knabner I, Amelung W (2014) Dynamics, chemistry, and preservation of organic matter in soils. In: Turekian HDHK (ed) Treatise on geochemistry, Second edn. Elsevier, Oxford, pp 157-215. doi:10. 1016/B978-0-08-095975-7.01012-3

Kong L-L, Liu W-T, Zhou Q-X (2014) Biochar: An effective amendment for remediating contaminated soil. In: Whitacre DM (ed) Reviews of Environmental Contamination and Toxicology, vol 228. Reviews of Environmental Contamination and Toxicology. pp 83-99. doi:10. 1007/978-3-319-01619-1_4

Kookana RS (2010) The role of biochar in modifying the environmental fate, bioavailability, and efficacy of pesticides in soils: a review. Aust J Soil Res 48:627-637. doi:10.1071/SR10007

Kookana RS, Sarmah AK, Van Zwieten L, Krull E, Singh B (2011) Biochar application to soil: agronimic and environmental benefits and unintended consequences. In: Sparks DL (ed) Advances in agronomy, vol 112. Elsevier Academic Press Inc, San Diego, pp 103-143. doi:10.1016/b978-0-12-385538-1.00003-2

Kusmierz M, Oleszczuk P (2014) Biochar production increases the polycyclic aromatic hydrocarbon content in surrounding soils and potential cancer risk. Environ Sci Pollut Res 21(5):3646-3652. doi:10. 1007/s11356-013-2334-1

Laird DA (2008) The charcoal vision: a win-win-win scenario for simultaneously producing bioenergy, permanently sequestering carbon, while improving soil and water quality. Agron J 100(1):178-181. doi:10.2134/agrojnl2007.0161

Lal R (2006) Enhancing crop yields in the developing countries through restoration of the soil organic carbon pool in agricultural lands. Land Degrad Dev 17(2):197-209. doi:10.1002/ldr.696

Lal R, Follett RF, Stewart BA, Kimble JM (2007) Soil carbon sequestration to mitigate climate change and advance food security. Soil Sci 172(12):943-956

Leach M, Fairhead J, Fraser J (2012) Green grabs and biochar: revaluing African soils and farming in the new carbon economy. J Peasant Stud 39(2):285-307. doi:10.1080/03066150.2012.658042

Lehmann J, Rondon M (2006) Bio-char soil management on highly weathered soils in the humid tropics. In: Uphoff N (ed) Biological Approaches to Sustainable Soil Systems. New York, pp 517-530. doi:10.1201/9781420017113.ch36

Libra JA, Ro KS, Kammann C, Funke A, Berge ND, Neubauer Y, Titirici M-M, Fühner C, Bens O, Kern J, Emmerich K-H (2011) Hydrothermal carbonization of biomass residuals: a comparative review of the chemistry, processes and applications of wet and dry pyrolysis. Biofuels 2(1):71-106. doi:10.4155/bfs.10.81

Liu X, Zhang A, Ji C, Joseph S, Bian R, Li L, Pan G, Paz-Ferreiro J (2013) Biochar's effect on crop productivity and the dependence on experimental conditions-a meta-analysis of literature data. Plant Soil 373(1-2):583-594. doi:10.1007/s11104-013-1806-x

Liu T, Liu B, Zhang W (2014) Nutrients and heavy metals in biochar produced by sewage sludge pyrolysis: its application in soil amendment. Pol J Environ Stud 23(1):271-275

Lucchini P, Quilliam RS, DeLuca TH, Vamerali T, Jones DL (2014) Increased bioavailability of metals in two contrasting agricultural soils treated with waste wood-derived biochar and ash. Environ Sci Pollut Res 21(5):3230-3240. doi:10.1007/s11356-013-2272-y

Lysenko G, Squires V, Verheye WH (eds) (2010) Interactions-food, agriculture and environment: Volume II. Enceyclopsdia of life support systems. EOLSS Publishers Co Ltd, Singapore

Macdonald LM, Farrell M, Lv Z, Krull ES (2014) Plant growth responses to biochar addition: an Australian soils perspective. Biol Fertility Soils. doi:10.1007/s00374-014-0921-z

Miltner BC, Coomes OT (2015) Indigenous innovation incorporates biochar into swidden-fallow agroforestry systems in Amazonian Peru. Agrofor Syst 89(3):409-420. doi:10.1007/s10457-014-9775-5

Mueller ND, Gerber JS, Johnston M, Ray DK, Ramankutty N, Foley JA (2012) Closing yield gaps through nutrient and water management. Nature 490(7419):254-257. doi:10.1038/nature11420

Mukherjee A, Lal R (2013) Biochar impacts on soil physical properties and greenhouse gas emissions. Agronomy 3(2):313-339. doi:10. 3390/agronomy3020313

Mukherjee A, Lal R, Zimmerman AR (2014) Effects of biochar and other amendments on the physical properties and greenhouse gas emissions of an artificially degraded soil. Sci Total Environ 487:26-36. doi:10.1016/j.scitotenv.2014.03.141

Naeem MA, Khalid M, Arshad M, Ahmad R (2014) Yield and nutrient composition of biochar produced from different feedstocks at varying pyrolytic temperatures. Pak J Agric Sci 51(1):75-82

Nelissen V, Saha BK, Ruysschaert G, Boeckx P (2014) Effect of different biochar and fertilizer types on $\mathrm{N} 2 \mathrm{O}$ and $\mathrm{NO}$ emissions. Soil Biol Biochem 70:244-255. doi:10.1016/j.soilbio.2013.12.026

Nigh R, Diemont SAW (2013) The Maya milpa: fire and the legacy of living soil. Front Ecol Environ 11:E45-E54. doi:10.1890/120344

Novak JM, Busscher WJ (2013) Selection and use of designer biochars to improve characteristics of southeastern USA coastal plain degraded soils. In: Lee JW (ed) Advanced Biofuels and Bioproducts. Springer New York, pp 69-96. doi:10.1007/978-1-4614-3348-4_7

Novak JM, Busscher WJ, Laird DL, Ahmedna M, Watts DW, Niandou MAS (2009) Impact of biochar amendment on fertility of a southeastern coastal plain soil. Soil Sci 174(2):105-112. doi:10.1097/SS. 0b013e3181981d9a

Novak JM, Cantrell KB, Watts DW, Busscher WJ, Johnson MG (2014) Designing relevant biochars as soil amendments using lignocellulosic-based and manure-based feedstocks. J Soils Sed 14(2):330-343. doi:10.1007/s11368-013-0680-8

Obia A, Mulder J, Martinsen V, Cornelissen G, Børresen T (2016) In situ effects of biochar on aggregation, water retention and porosity in light-textured tropical soils. Soil Tillage Res 155:35-44. doi:10. 1016/j.still.2015.08.002

OECD (2012) Measuring R\&D in developing countries; Annex to the Frascati Manual: OECD (2002) Frascati Manual 2002: proposed standard practice for surveys on research and experimental development. doi: 10.1787/9789264199040-en. Organisation for Economic Co-operation and Development (OECD), Paris

Oldeman LR (1994) Global extent of soil degradation ISRIC Bi-Annual Report 1991-1992. International Soil Reference and Information Centre (ISRIC), Wageningen

Oldeman LR, Hakkeling RTA, Sombroek WG (1991) World map of the status of human-induced soil degradation. International Soil Reference and Information Centre. United Nation Environment Program, Wageningen and Nairobi

Organisation for Economic Co-operation and Development (2008) Measuring sustainable production. OECD sustainable 
development studies. OECD Publishing, Paris. doi:10.1787/ 9789264044135-en

Paul H, Ernsting A, Semino S, Gura S, Lorch A (2009) Agriculture and climate change: real problems, false solutions. EcoNexus, Oxford

Pavlovic NJ, Mandel DR (2011) Aggregating indices of governance quality: an exploratory factor analysis. Defence Research and Development Canada, Toronto

Pietrobelli C, Rabellotti R (2011) Global value chains meet innovation systems: are there learning opportunities for developing countries? World Dev 39(7):1261-1269. doi:10.1016/j.worlddev.2010.05.013

Preston CM, Schmidt MWI (2006) Black (pyrogenic) carbon: a synthesis of current knowledge and uncertainties with special consideration of boreal regions. Biogeosciences 3(4):397-420. doi:10.5194/bg-3397-2006

Prost K, Borchard N, Siemens J, Kautz T, Sequaris J-M, Möller A, Amelung W (2013) Biochar properties affected by composting with farmyard manure. J Environ Qual 42(1):164-172. doi:10.2135/ jeq2012.0064

Saranya K, Kumutha K, Krishnan PS (2011) Influence of biochar and Azospirillum application on the growth of maize. Madras Agricultural Journal 98(4/6):158-164

Schmidt MWI, Torn MS, Abiven S, Dittmar T, Guggenberger G, Janssens IA, Kleber M, Koegel-Knaber I (2011) Persistence of soil organic matter as an ecosystem property. Nature 478:49-56. doi:10. 1038/nature10386

Schmidt PH, Pandit HB, Martinsen V, Cornelissen G, Conte P, Kammann IC (2015) Fourfold increase in pumpkin yield in response to lowdosage root zone application of urine-enhanced biochar to a fertile tropical soil. Agriculture 5(3). doi:10.3390/agriculture5030723

Schulz H, Dunst G, Glaser B (2013) Positive effects of composted biochar on plant growth and soil fertility. Agron Sustain Dev 33(4): 814-827. doi:10.1007/s13593-013-0150-0

Schulz H, Dunst G, Glaser B (2014) No effect level of co-composted biochar on plant growth and soil properties in a greenhouse experiment. Agronomy 4(1):34-51. doi:10.3390/agronomy4010034

Singh Y, Sidhu HS (2014) Management of cereal crop residues for sustainable rice-wheat production system in the indo-gangetic plains of India. Proc Indian Natl Sci Acad 80(1):95-114

Sohi S, Krull E, Lopez-Capel E, Bol R (2010) A review of biochar and its use and function in soil. Adv Agron 105:47-82. doi:10.1016/S00652113(10)05002-9

Sparrevik M, Field JL, Martinsen V, Breedveld GD, Cornelissen G (2013) Life cycle assessment to evaluate the environmental impact of biochar implementation in conservation agriculture in Zambia. Environ Sci Technol 47(3):1206-1215. doi:10.1021/es302720k

Steinberger JK, Roberts JT, Peters GP, Baiocchi G (2012) Pathways of human development and carbon emissions embodied in trade. Nat Clim Chang 2(2):81-85. doi:10.1038/nclimate1371

Sustainable Development Solutions Network (2015) Indicators and a monitoring framework for the sustainable development goals: launching a data revolution for the SDGs. Sustainable Development Solutions Network (SDSN), Paris and New York

Uman LS (2011) Systematic reviews and meta-analyses. Journal of the Canadian Academy of Child and Adolescent Psychiatry 20(1):5759

UN (2015) Transforming our world: the 2030 agenda for sustainable development, vol A/RES/70/1. United Nations (UN), New York

UNDP (2010) Human development report 2010 - the real wealth of nations: pathways to human development. Human development reports. United Nations Development Programme (UNDP), New York

van Groenigen KJ, Osenberg CW, Hungate BA (2011) Increased soil emissions of potent greenhouse gases under increased atmospheric CO2. Nature 475(7355):214-216. doi:10.1038/nature10176

van Vliet N, Mertz O, Heinimann A, Langanke T, Pascual U, Schmook B, Adams C, Schmidt-Vogt D, Messerli P, Leisz S, Castella J-C, Jørgensen L, Birch-Thomsen T, Hett C, Bech-Bruun T, Ickowitz A, Vu KC, Yasuyuki K, Fox J, Padoch C, Dressler W, Ziegler AD (2012) Trends, drivers and impacts of changes in swidden cultivation in tropical forest-agriculture frontiers: a global assessment. Glob Environ Chang 22(2):418-429. doi:10.1016/j.gloenvcha.2011.10. 009

Venables WN, Ripley BD (2003) Modern applied statistics with S. Springer, New York

Verheijen F, Diafas I, Jeffery S, Bastos A, Valde MVD (2010) Biochar application to soils: a critical scientific review of effects on soil properties, processes and functions. European Commission Joint Research Centre, Brussels

von Grebmer K, Headey D, Béné C, Haddad L, Olofinbiyi T, Wiesmann D, Fritschel H, Yin S, Yohannes Y, Foley C, von Oppeln C, Iseli B (2013) Global hunger index: the challenge of hunger: building resilience to achieve food and nutrition security. Welthungerhilfe, International Food Policy Research Institute, Concern Worldwide, Bonn, Washington, DC, Dublin. doi:10.2499/9780896299511

von Lützow M, Kögel-Knabner I, Ekschmitt K, Matzner E, Guggenberger G, Marschner B, Flessa H (2006) Stabilization of organic matter in temperate soils: mechanisms and their relevance under different soil conditions - a review. Eur J Soil Sci 57(4):426445. doi:10.1111/j.1365-2389.2006.00809.x

Wardle DA, Nilsson M-C, Zackrisson O (2008) Fire-derived charcoal causes loss of forest humus. Science 320(5876):629-629. doi:10. 1126/science. 1154960

Wollenberg E, Richards M, Smith P, Havlík P, Obersteiner M, Tubiello FN, Herold M, Gerber P, Carter S, Reisinger A, van Vuuren DP, Dickie A, Neufeldt H, Sander BO, Wassmann R, Sommer R, Amonette JE, Falcucci A, Herrero M, Opio C, Roman-Cuesta RM, Stehfest E, Westhoek H, Ortiz-Monasterio I, Sapkota T, Rufino MC, Thornton PK, Verchot L, West PC, Soussana J-F, Baedeker T, Sadler M, Vermeulen S, Campbell BM (2016) Reducing emissions from agriculture to meet the $2{ }^{\circ} \mathrm{C}$ target. Glob Chang Biol. doi:10.1111/ gcb. 13340

Zhang A, Bian R, Pan G, Cui L, Hussain Q, Li L, Zheng J, Zheng J, Zhang X, Han X, Yu X (2012) Effects of biochar amendment on soil quality, crop yield and greenhouse gas emission in a Chinese rice paddy: a field study of 2 consecutive rice growing cycles. Field Crop Res 127:153-160. doi:10.1016/j.fcr.2011.11.020

Zhang X, Wang H, He L, Lu K, Sarmah A, Li J, Bolan NS, Pei J, Huang H (2013) Using biochar for remediation of soils contaminated with heavy metals and organic pollutants. Environ Sci Pollut Res 20(12): 8472-8483. doi:10.1007/s11356-013-1659-0

Zhang B, Cao C, Gu J, Liu T (2016) A new environmental protection law, many old problems? Challenges to environmental governance in China. Journal of Environmental Law 28(2):325-335. doi:10. 1093/jel/eqw014

Zimmermann M, Bird MI, Wurster C, Saiz G, Goodrick I, Barta J, Capek P, Santruckova H, Smernik R (2012) Rapid degradation of pyrogenic carbon. Glob Chang Biol 18(11):3306-3316. doi:10.1111/j.13652486.2012.02796.x 